\title{
SDC3 wt Allele
}

National Cancer Institute

\section{Source}

National Cancer Institute. SDC3 wt Allele. NCI Thesaurus. Code C118951.

Human SDC3 wild-type allele is located in the vicinity of 1 p35.2 and is approximately $39 \mathrm{~kb}$ in length. This allele, which encodes syndecan-3 protein, plays a role in both the biosynthesis and catabolism of glycosaminoglycans. Single-nucleotide polymorphisms in the gene are associated with obesity in some ethnic groups. 